\title{
The Myth of the Fourth Industrial Revolution
}

\author{
Ian Moll
}

Abstract: This article argues that there is no such phenomenon as a Fourth Industrial Revolution. It derives a framework for the analysis of any industrial revolution from a careful historical account of the archetypal First Industrial Revolution. The suggested criteria for any socioeconomic transformation to be considered an industrial revolution are that it must encompass a technological revolution; a transformation of the labour process; a fundamental change in workplace relations; new forms of community and social relationships; and global socio-economic transformations. These transformations indeed characterise the Second and Third Industrial Revolutions. The aggregate of technical innovations in the latter is carefully examined, because this is a crucial part of determining whether we can meaningfully claim that a Fourth Industrial Revolution is underway. The article demonstrates that we cannot.

Keywords: Africa, colonisation, Fourth Industrial Revolution, information technology, labour process, social change, Third Industrial Revolution, workplace relations

The Fourth Industrial Revolution (4IR) is all the rage these days. Enthusiasts point to an apparently staggering array of 'new' technologies - usually digital - that sound smart and make us feel outdated and in awe of the future: technologies like blockchain, big data, artificial intelligence, the Internet of Things and fully autonomous killer robots. They declare that these technologies are converging in unprecedented ways, and predict changes that will transform every part of our lives. But are these dramatic new entrants really revolutionising our world in the way that we are told? 
The argument in this article is that a 4IR is not yet upon us, and that there is little evidence that it is on the horizon. A careful analysis of the First, Second and Third Industrial Revolutions will demonstrate that an industrial revolution encompasses a complex, mutually generative range of economic, social and political transformations. The First Industrial Revolution (1IR) was a period of fundamental, transcontinental change characterised by the complex conjunction of socio-economic practices and innovations. As the archetypal industrial revolution, it provides historians a framework of analysis that can be used to determine whether any period of substantial development can be considered to be an industrial revolution. The key features of the Second and Third Industrial Revolutions clearly meet the criteria in this framework, demonstrating that the socio-economic transformations that occurred during these periods were, indeed, industrial revolutions. However, the argument here is that the same cannot be said about the alleged 4IR. Changes in the twenty-first century are generally the continued evolution of the Third Industrial Revolution (3IR).

\section{The First Industrial Revolution: 1760-1850}

Two contrasting narratives of the 1IR predominate in the popular imagination. ${ }^{1}$ The first tells a triumphant story of Britain's rise to prosperity and global dominance through rapid industrialisation and increased productivity made possible by a sudden explosion of technological innovation. It invokes the fantastical image of George Stephenson driving 'Rocket', the first operational steam locomotive, down a railway line through crowds of cheering, top-hatted men. In this story, the 1IR was 'fundamentally a technological revolution [focused on] the sources of invention' (Allen 2006: 2). The second narrative highlights the degradation of the working class and the appalling working and living conditions associated with the rise of large factories and crowded cities. In this picture, 'an exploited and dispirited army of men, women and children is engaged for starvation wages in a seemingly endless round of drudgery ... the sole beneficiary of their efforts is the grasping, tyrannical, licentious factory master' (Bythell 1983: 17). 
While both of these narratives are obviously oversimplified, together they capture the rise of the factory and the tension between the massively increased economic production and massively degraded social structures that characterised the 1IR. While technological innovations contributed to this revolution, it was driven by socio-economic forces. The interaction between the economic, political, social and technological changes that took place during this period, locally and globally, brought about the kind of fundamental and sustained transformation that historians term a 'revolution'.

The dramatic rise of the merchant bourgeoisie underlies the overturning of social and political norms during the 1IR. While political power in Britain up to the 1700s had been concentrated in the hands of a small, landed aristocracy driving a feudal economy, over several decades a system of proto-industries began developing which supplied goods to Britain's rapidly expanding colonial markets. It was not the aristocracy that benefitted most from this 'domestic cottage system', however, but a rising class of increasingly wealthy merchants.

As demand from British consumers and colonies in India, North America and the Caribbean increased, cottage industries simply could not make enough quickly enough. As large-scale factories arose to meet the demand of Britain's global market, the cottage industries collapsed. Duncan Bythell (1983) notes that the same merchant-manufacturers who had profited from the organised cottage industry system turned their backs on it and became the new factory owners of the rising capitalist order.

Enabling this industrial transformation was a fleet of technological innovations. Jeremy Greenwood (1999) notes that 'for the economy as a whole to switch from manual techniques to mechanised production required hundreds of inventors, thousands of innovating entrepreneurs, and tens of thousands of mechanics, technicians, and dexterous rank and file workers' (1999: 8). In 1781, James Watt's innovative steam engine, which could be harnessed to power machines in factories, was an iconic invention of this period, as was Stephenson's 'Rocket' in 1830. John Kay's flying shuttle, James Hargreaves' spinning jenny, Samuel Crompton's spinning mule and other new machines dramatically increased productivity in the textile 
industry: in 1800, for example, a cotton spinner could spin 200 times as much in a day as they could in 1700 (BBC n.d.). In America, Eli Whitney invented the cotton gin, a machine that separated cotton fibres from their seeds. Other technologies developed rapidly across industries - notably, machinery and metal-working procedures for factories (Greenwood 1999). Paul Kennedy proposes that 'no earlier technological breakthroughs produced anything like the rise in output that flowed from the Industrial Revolution' (1993: 8).

However, this rapid development of the technologies of production brought with it the appalling labour processes characteristic of the 1IR factory. Kennedy describes the plight of British workers at the end of the eighteenth century: 'Suffering under awful conditions in factories and mines, they were organised alongside their machines in a strict, time-driven system of labour unlike anything known previously' (1993: 8). In contrast to work in the preindustrial cottage system, factory workers lost autonomy in the work process. Children, too, often worked in the most exploitative conditions possible; they were paid the least and forced to work in the most dangerous situations (Humphries 2013). Friedrich Engels (1845) aptly summed up the workers' plight thus: 'The industrial revolution has simply carried this [the exploitation of workers] out to its logical end by making the workers machines pure and simple, taking from them the last trace of independent activity'.

The clear hierarchy of workers and bosses - whose interests differed fundamentally - became the crucible in which new social classes began to form. E. P. Thompson suggests that 'the outstanding fact' of the 1IR was the 'formation of the working class' (1963: 194). Bythell notes that 'because ownership of these machines, of the building which houses them and the engine which drives them, rests with the private capitalist, there exists an unbridgeable gulf between him and his property-less, wage-earning employees' (1983: 17-18). It is no wonder that the issues surrounding labour in the factories of the 1IR provided fertile ground for the rallying call of the Communist Manifesto in 1848:

The modern bourgeois society that has sprouted from the ruins of feudal society has ... simplified class antagonisms. Society as a whole is more and more splitting up into two great hostile camps, into two great classes directly facing each other - bourgeoisie and proletariat. (Marx and Engels 1848: 14-15) 


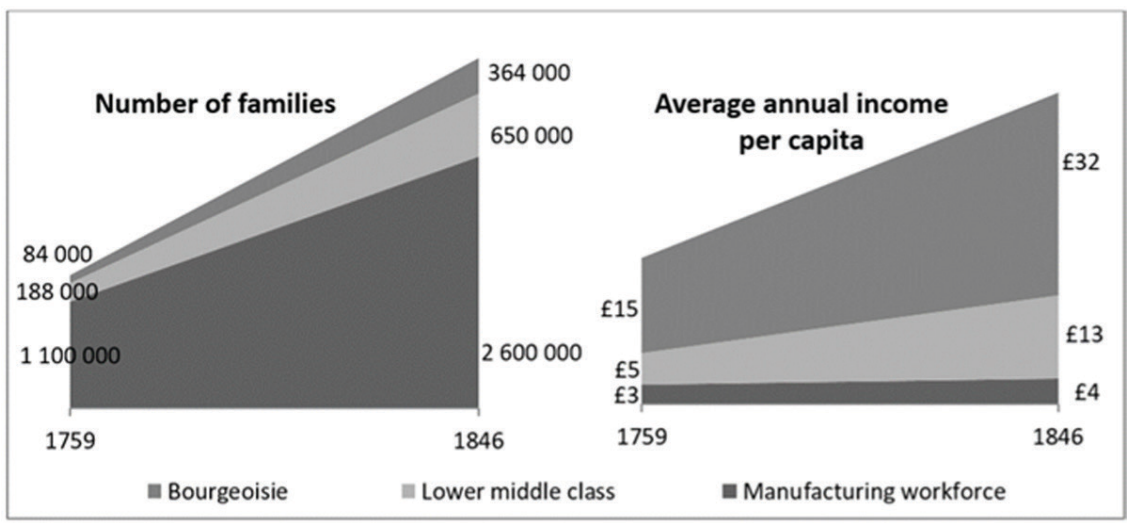

Figure 1. Increase in Number of Families and Income per Capita for Three Classes in British Society: 1759-1846 (Statistics are from Allen 2019)

Despite economic growth, this social cleavage permeated and consolidated itself in British society. As C. Grove Haines and Warren B. Walsh put it, 'poverty stalked in the midst of plenty. While statistics revealed steadily mounting material welfare and the growth of national and per capita wealth, hundreds of thousands of wretchedly poor filled the slums of the great urban communities' (1941: 653). Figure 1 illustrates the increase in the number of families and the increase in average annual income per capita in the bourgeoisie, lower middle class and manufacturing workforce from 1759 to 1846 . Average annual income per capita rose sharply for the bourgeoisie during this period, but it hardly grew at all for the manufacturing workforce.

Factories thus represented major industrial growth, but the social consequences were devastating for the rural people whose livelihoods were torn out from under them by the Industrial Revolution. Tens of thousands flocked to the fast-growing cities and factory towns in search of work, although many remained unemployed. Conditions were often appalling; lack of adequate housing and services had a direct impact on health. Kennedy describes the conditions that emerged: 'In the crowded cities ... garbage was thrown into the streets, rivers were polluted, and deaths from diseases such as cholera, smallpox, typhoid, and tuberculosis multiplied' (1993: 96). Eric Hobsbawm (1962) notes that it was only when these conditions began to pose a threat to the wealthy that something was 
done to intervene in the steady deterioration of the living conditions of the working class.

The changes that first appeared to be localised in Britain were also enabled, and substantially driven, by its network of transcontinental trade. From the mid-eighteenth century onwards, Britain was the dominant colonial power, working on a liberal, free-trade economic model that itself was generated by the emerging imperialism of the 1IR (Lange et al. 2006). Cotton and textiles dominated Britain's systems of production, distribution and consumption that globalised the 1IR - despite the irony that Britain produced no cotton. Harvard historian Sven Beckert makes the case that cotton was the 1IR's 'launching pad' (2014: 23): while wool and flax had traditionally been used to make textiles and clothing, cotton's strong fibres were better suited to the mechanical processes of spinning and weaving machinery.

From the sixteenth century onwards, British and other European traders had purchased cotton textiles in India. After Britain's conquest of India, however, it was able to exploit its resources directly. Raw cotton was extracted from India, manufactured into textiles and clothing in Britain and sold back into India at a significant profit. India's 'homespun' proto-industries were quickly undermined, wreaking economic devastation.

Britain's colonies in the Americas soon yielded even cheaper cotton, supplying over 80 per cent of the raw material used in Britain's textile and clothing industry (Dattel 2009). As slave labour was the key to the profitability of this arrangement, the dramatic increase in the transport of slaves from Africa to American plantations in the late eighteenth century can be linked to the production of cotton for Britain's factories. The brutal work conditions and high mortality rate amongst slaves shipped to the plantations demanded more and more slaves to maintain production levels. Trinidadian historian Eric Williams (1944) argues that slavery funded the Industrial Revolution in Britain because the transatlantic slave trade provided a 'triple stimulus' to industry in Britain. It worked like this:

African people were captured and sold onto ships, and transported across the Atlantic to become slaves on plantations in the Americas. The cotton that they produced was transported across the Atlantic to the burgeoning textile factories in the north of England. Much of the cloth produced in these factories was then transported down the Atlantic 
coastline, as the most desired currency used by British traders to buy slaves in Africa. (Moll 2020)

Whether slavery played a key role in financing the Industrial Revolution or not, the political, economic, social and labour realities of this 'triangular trade' were an integral part of the 1IR. The 1IR was realised through slavery and cotton.

\section{Criteria for an Industrial Revolution}

Historians regard (or construct) the 1 IR as the archetypal industrial revolution (Cannadine 1984; Coleman 1992; Hobsbawm 1997; Stearns 2012). Malcolm Falkus (1987) points out that, while some economic historians have considered a period of short-term economic acceleration a revolution, the dominant view is that for a period of change to 'count' as a revolution it must be characterised by long-term socio-economic change at a fundamental, or structural, level. Karl Polanyi's (1945) insights in this regard are crucial: prior to the industrial revolutions, the socio-economic mentality of people was based on communal systems of reciprocity and redistribution; the consequence of industrialisation was the institutional construction of a competitive market society regulated by the State. This 'great transformation' was established in Britain in the 1IR, and consolidated globally in the 2IR. It was not simply an accumulation and confluence of inventions.

There seem to be good reasons to avoid this kind of economic reductionism. Historians, as opposed to economists, generally understand industrial revolutions in broader socio-economic terms as complex ensembles of technological, economic, social, political and cultural change that unfold globally over time. The analysis of the 1IR above has clearly adopted this perspective. It seeks, for example, to go beyond a tradition in evolutionary economics that draws on Kondratieff wave theory and Joseph Schumpeter's notion of creative destruction to construe industrial revolutions as "techno-economic paradigms" (e.g. Freeman and Louçã 2001; Perez 2002). Nikolai Kondratieff (1935) posited technology-driven historical cycles of economic prosperity every fifty years or so, but his models reduce socio-economic changes to purely technological 
and value-related economic phenomena. Schumpeter extended this idea in his notion of 'industrial mutations', processes that 'incessantly revolutionized the economic structure from within' to make way for innovation (1943: 83). Besides this reductionism, these theorists worked largely with data about Western Europe and the United States, which may not hold for the world economy as a whole (Wallerstein 1984). Another problem is that the post-Kondratieff tradition seeks to specify 'techno-industrial' or 'technoscientific' revolutions (say a 4IR) by an unfortunate teleology that projects 'long waves' into the future on a recapitulationist evolutionary logic (although Kondratieff himself was sceptical of such teleology [Mustafin 2018], and there is a suggestion that Schumpeter may have been too [Papageorgiou and Michaelides 2016]).

Instead, the analytical approach in this article treats industrial revolutions as fundamental transformations across multiple social and economic dimensions which impact each other in complex ways and have a global impact - hence the use of the term 'socioeconomic' to grasp this complexity. The social transformation that resulted from the 1IR was a profound combination of material progress and social suffering that was so wide-ranging that it warrants the term 'revolutionary'. It was far more than a period of intense technological innovation or a merging - or emerging - of technologies. While this transformation was centred in a particular society (Britain) over the course of nearly a century, it had ramifications and lasting consequences for the whole world.

By identifying the key elements which constituted the 1IR as an industrial revolution, we can construct an analytical framework which can be applied to other periods of significant change to evaluate whether they legitimately constitute industrial revolutions. These characteristics can be used as criteria for this analysis. An industrial revolution, in its socio-economic entirety, must entail:

- A technological revolution characterised by widespread, connected innovation;

- Transformation of the labour process or the 'nature of work';

- Changing labour relations in the workplace and their social ramifications;

- Fundamental changes in everyday social life (notably in cities); and 
- Global transformation related to international trade and agglomerations of power.

\section{The Second Industrial Revolution: 1865-1914}

A defining feature of the 2IR is that global expansion was no longer centred on the industrial economy of one dominant country, as it had been in the 1IR. By the 1880s, Germany, France, Belgium, Italy, Britain, the United States, Denmark, the Swedish-Norwegian Union and Japan constituted a global industrial nexus: 'No country outside of this "developed world" could be described as industrial or even on the way to industrialization' (Hobsbawm 1989: 21). Not only did the geographic spread and diversity of technological innovation connect the giant industrial corporations, but it also deepened economic activity in general: 'The great pathbreaking inventions ... were crucial not because they themselves had necessarily a huge impact on production, but because they increased the effectiveness of micro-inventive activity' across the entire economy (Mokyr 1998: 219).

New technological marvels dominated the 2IR. By 1870, technologies originating in the IIR had established an extensive infrastructure for trade and commerce: harbours, railway and telegraph networks in Europe and North America had shifted 'the large technological system from an exception to a commonplace' (Mokyr 1998: 220). Hobsbawm notes that 'modern technology was not only undeniable and triumphant, but highly visible' (1989: 27). While the key inventions of the 1IR tended to be connected within the walls of factories, the new technologies of the 2IR revolutionised daily life in industrialised countries. While electricity was not discovered in the 2IR, the large-scale generation of power was one of its most significant achievements, paving the way for electric machinery in production and lighting in factories, streets and homes. Cheap, quality steel became generally available after open-hearth furnaces were invented in Germany in 1865, enabling large-volume steel production. Petrol was discovered with the invention of the motor car. German, British, American and Italian inventors contributed internal combustion engines, diesel engines, telephones, light bulbs, skyscrapers, aeroplanes, plastic and the first transatlantic radio signal. 
Large corporations brought in a significant transformation of the labour process. Frederick Taylor's (1911) ideas about organising factory workers to maximise productivity through a division of labour that matched specific workers to specific tasks, supported by increased training and supervision, were hugely influential. Part of his assembly line entailed the precise manufacture of interchangeable parts for efficient high-volume manufacture. In 1913, the Ford Motor Company introduced automated assembly lines into its factories, after Taylor analysed its production processes, and was soon rolling out up to 10,000 Model-Ts a day. The automated assembly line was adopted by many industries and became a key feature of the 2IR. While critics accused Taylor of dehumanising and deskilling workers by focussing only on the control of labour and the costs of production (Braverman 1998), 'Taylorism' was implemented across the United States and the Soviet Union (Scoville 2001).

By 1865 , very large factories began to emerge, which were characterised by a hierarchy of workers, supervisors and bosses. Their conflicting interests sparked the most significant change in the social relations of the workplace in history: the legalisation and formal consolidation of the trade union. While thousands of British workers had formed trade unions in the 1IR, these had been supressed by force and curtailed by law. Well into the 1800 s, workers in the United States and parts of Europe had organised frequent strikes, often facing severe retaliation. However, factory outputs were also negatively affected, and politicians and capitalists began to consider whether trade unions could not serve their interests as well. By the late $1800 \mathrm{~s}$, trade unions were unbanned across the industrial world and 'labour aristocracies' incorporated into the socio-economic landscape of industrial capitalism (McLennan 1981).

These inherent social contradictions also manifested, paradoxically, in a period of relative social stability: technology brought increasing prosperity and some improvements to living conditions; at the same time, the working classes grew increasingly resentful about their social situation in relation to the massive wealth increases of the upper classes. Hobsbawm observes that the haphazard migration to cities in the nineteenth century initially produced 'class segregation, which pushed the new labouring poor into great morasses of misery outside the centres of government and business 
and the newly specialised residential areas of the bourgeoisie' (1962: 203). However, growing social movements focussed on poverty, housing and public health also emerged. Urban planning, which originated in Germany and spread through the industrialised world, was seen by governments as an intervention to 'restore order' and consider how cities should be organised and managed (Hall 2014). Joel Mokyr (1998) provides compelling evidence that from 1870, across Europe and the United States, infant mortality declined significantly and life expectancy increased. Working people received somewhat higher incomes, lived in less congested housing and had access to running water, sewage and medical care. Hobsbawm sums up the contradictions of the 2IR thus:

It was an era when massive organised movements of the class of wage workers ... suddenly emerged and demanded the overthrow of capitalism. But they emerged in highly flourishing and expanding economies $\ldots$ at a time when capitalism offered them slightly less miserable conditions than before. (Hobsbawm 1989: 10)

It is significant that many of the socialist and labour political parties that exist today in the industrialised world were formed at the height of the 2IR.

On a global scale, the 2IR (despite the abolition of slavery) entrenched the colonial relationships established in the 1IR even more deeply. Again, Hobsbawm writes:

The major fact about the nineteenth century is the creation of a single global economy ... an increasingly dense web of economic transactions, communications and movements of goods, money and people linking the developed countries with each other and with the undeveloped world. (Hobsbawm 1989: 62)

It is no historian's accident that the 2IR coincides with the 'Age of Imperialism' from the 1860 s to 1914 . The economic and technological prosperity of the period was intimately bound up with the subjugation and economic exploitation of the colonised world. Andre Gunder Frank's (1971) description of the rest of the world as 'underdeveloped', rather than 'undeveloped', recognises that the industrialised nations of the 2IR systematically exploited their colonies, creating and maintaining in them a state of dependency. The colonies continued to provide markets for commodities produced 
in the factories of the north, while these nations, on their part, continued to 'depend' on raw materials and commodities from their colonies, which could be produced cheaply by exploiting local, often forced, labour (Pollard and Holmes 1972).

Between 1876 and 1914, about one-quarter of the world was colonised by Britain, France, Germany, Belgium, Italy and the United States - the 'global industrial nexus'. The 'scramble for Africa' demonstrated dramatically the imperialist nature of the economies of the industrialised nations. In the 1880 s, 80 per cent of Africa still remained under traditional and local control. However, the industrial powers were rapidly growing more interested in Africa's raw materials and potential markets, and in 1885 convened the Berlin Conference to pre-empt potential conflicts amongst themselves. They drafted a declaration focussed overwhelmingly on ensuring free trade for themselves in Africa. Immediately following its signing, the colonial powers parcelled out virtually all of Africa amongst themselves. The delegates drew the future boundaries of Africa, and 'apart from some localised detail, paid scant regard to Africa, let alone to Africans' (Griffiths 1986: 204). The Berlin Conference thus established imperialism in Africa, and the agreement that it reached was a central legal mechanism of the 2IR.

The period 1865-1914 meets all of the criteria to qualify as an industrial revolution:

1. Technological revolution: widespread innovation arising from the development of steel, electricity, petrol and industrial chemistry;

2. Transformation of the labour process: the assembly line and interchangeable parts transformed work in factories;

3. Changing work relations in the workplace: the competing interests of factory owners and workers intensified, leading to the recognition of trade unions and the emergence of socialist political parties;

4. Changing community and social relations: social cleavages between the rich and poor were consolidated - for example, in the management of cities; and

5. International/global transformation: colonialism was systematised, and the economic exploitation associated with it was intensified. 


\section{A Lull between Industrial Revolutions: 1915-1960}

The 2IR is generally considered by historians to have ended by 1915 and the 3IR to have begun in the 1960s. What about the four decades in between? This was, after all, a period of dramatic world history: the First and Second World Wars and the Cold War - with its arms and space races - accelerating the pace of technological innovation; deep economic depression between the two world wars and the 'golden age of capitalism' of the 1950s and 1960s; and the achievement of formal independence by most colonised nations (if not the ending of colonisation). So why did this not count as an industrial revolution? Hobsbawm's answer in relation to the technological innovations of war seems generalisable to the whole period:

Wars, especially the Second World War, greatly helped to diffuse technical expertise, and they certainly had a major impact on industrial organization and methods of mass production, but what they achieved was, by and large, an acceleration of change rather than a transformation. (Hobsbawm 1995: 48)

There were indeed many technological innovations during this period: the First World War sped up aeronautics; the Second World War produced rocket technology, enhanced radio technology, improved plastics, and, most sobering of all, gave us nuclear fission. The motor industry up to the 1960 s produced many innovations. In 1947, the transistor was invented - accelerating the field of electronics, leading to the first portable radios and a new generation of computers in the 1950s. Yet the technological innovations of the period tended to be very much the technologies of the 2IR continuing to spur industrial development.

Labour relations and social conditions remained much the same through the two world wars and the deep economic depression between them. One social indicator of this is that trade unions lost half their membership from 1920 to 1932 (Hobsbawm 1995). By 1948, world trade was not significantly higher in volume than before 1915 (Hobsbawm 1995). In the context of global economic crisis after the Second World War, the United States was largely self-sufficient; other industrial states tended to isolate themselves from external threats and focus on rebuilding social and political 
stability rather than on change. The 'golden age' following the 1950 s capitalist boom brought with it socio-economic and political rebuilding without much evidence that technological transformation inspired any social change (Marglin and Schor 1992; Milberg and Winkler 2009; Toniolo 1998).

In terms of global dynamics, Hobsbawm notes that 'what really exploded was the trade in industrial products, mainly between the industrial core countries' (1995: 269) - evidence of socio-economic consolidation rather than revolution. The 1950 s were dominated by anti-colonial struggles and the 1960 s by transitions to independence. Frantz Fanon's lament, in 1961, that the new leadership of African nations 'possesses neither industrialists nor financiers. The national bourgeoisie is not geared to production, invention, creation or work ... colonialism hardly left it any choice' (1961: 98), gives us some sense of why an industrial revolution did not have any impetus in the former colonies by that time.

This period illustrates the notion that rapid, widespread and significant technological innovation in a particular era does not necessarily constitute an industrial revolution. This, I argue, is the case in the current era as well. It is also 'an acceleration of change rather than a transformation'.

\section{The Third Industrial Revolution: 1960 to the Present}

The 3IR is variously known as the 'digital revolution', the 'information age' and the 'network society'. These descriptions capture the complexity of the socio-economic transformations of this era which, without a doubt, constitute an industrial revolution.

The iconic inventions of the 3IR have been the Internet and the World Wide Web (WWW). The Internet began in 1969 as a project supported by the US Department of Defense that aimed to link computers via standard telephone connections at a number of universities. This platform grew during subsequent decades, but remained relatively unknown until Tim Berners-Lee launched a document-linking structure on it in 1991, establishing open standards for defining and exchanging information. In 1993, Marc Andreesen released Mosaic, the first widely available browser. The Internet and the WWW emerged as powerful vehicles of socio-economic transformation. 
Most technological innovations of this period are related to this globalised computer network. Microelectronics has expanded exponentially from the $1960 \mathrm{~s}$, building on transistor technology. Integrated circuits and microprocessors made possible the personal computers of the 1980s, and cell phone and laptop computer technology from the 1990s. Programmable logic controllers - computers that control manufacturing processes by analysing real-time data - originated in the late 1960s in the US motor industry and have played a central role in subsequent industrial transformation. The Ethernet was invented in 1973, enabling interconnected local office networks, amongst other things. Robotics became an area of major 3IR technological innovation. The first digitally programmed robot was installed in a factory in 1961 (Engelberger 1985 ); by 2000 , there were some 750,000 industrial robots in the world (United Nations, cited in Wikipedia n.d.). Underlying all of this was the technology of digitisation: the encoding of analogue information into binary data which makes exchange of information between all digital devices possible: hence, the 'network society'.

Other areas of technological progress in the 3IR have depended increasingly on computerisation. In the 1970s, biotechnology saw the first use of computers to design drugs (Maulik and Patel 1997). The nuclear reactors built by many countries during the 3IR require computerised control systems to maintain stability. Satellite and other space technology, a highly significant aspect of the 3IR, relies on digital computer technology.

'Globalisation' is often used to describe the socio-economic transformations of the 3IR. While the 1IR depended on Britain's transcontinental 'triangular trade' and the 2IR was characterised by systematic colonialism, the fully globalised economy has been 'a new reality, different from processes of internationalization in previous times, for one simple reason: only at this point in history was a technological infrastructure available to make it possible' (Carnoy and Castells 2001: 3). The defining feature of globalisation is that all localities, regions and nation states have become networked in systematic capitalist production. Networked technology has enabled, indeed compelled, large corporations to trade outside national borders to maximise profit and reduce production costs. They have done this primarily by offshoring - relocating factories and operational process to other countries - or by outsourcing - having 
foreign companies perform aspects of operations. Beginning in the 1970s, many low-skill assembly operations were migrated to Mexico and Asia, while garment companies moved their manufacturing operations to 'sweatshops' in countries like India and Bangladesh. By the 1990s, services like software programming, call-centres and database administration were regularly outsourced to underdeveloped countries. Offshoring represented a major structural shift in which networked information technology infrastructures coordinate an intricate, dispersed set of economic activities, from supply chains to production processes to distribution networks to financial transactions, at sharply lower costs (Levy 2005; Milberg and Winkler 2009). These take the form of digitally dispersed Global Value Chains (GVCs) in which the production, trade and marketing of final goods are spread over several countries, with each one undertaking a discrete good or service. The consequence is the global fragmentation of trade across countries and an increasing emphasis on finance and the concealment of wealth rather than on production per se (Keane 2014; Seabrooke and Wigan 2014). GVCs 'hide, obscure and relocate wealth to the extent that they break loose from the location of value creation and heighten inequality' (Seabrooke and Wigan 2014: 257), which ramifies into structural consequences at every level of society.

Offshoring has had dramatic, international socioeconomic consequences. While there has been significant economic progress in the 3IR's globalised information economy, the critical role of networked ICTs in stimulating economic expansion is a 'double-edged sword' (Castells 1999). While some countries accelerated economic growth by introducing digital production systems, those that could not have become either increasingly marginalised or labour reservoirs for offshoring corporations. In the worst traditions of slavery and colonialism, the severe oppression and exploitation of the marginalised people and nations of the world has continued in the 3IR. Manuel Castells and Alejandro Portes make an insightful point in this regard:

It is often argued that uncontrolled, exploitative relationships ... [are not part of] advanced capitalism. But it is precisely the development of sweatshops and of other unregulated activities after a long period of institutional control that causes old forms of production to become new ones. (Castells and Portes 1989: 13) 
These exploitative - some might say neo-colonial - economic relations of globalisation have been an integral part of the 3IR.

The 3IR marked a shift beyond mining and manufacturing economies to a service economy, in which most jobs no longer create primary value (Hill 1987). Mines and factories are no longer managed on an individual, or even national, basis. They have become nodes on a massive global information system networked into every part of the manufacturing process and distributed all over the world (Castells 2000). With day-to-day operations managed globally, the production process has become primarily dependent on the management, flow and utilisation of information rather than on raw materials and energy. This has had major implications for the way that work is organised. In contrast to the 2IR trends to deskill workers and increase the division of labour on assembly lines, the much more flexible labour process of the 3IR has required fewer but more highly skilled workers with the expertise to manage global networks. Scaled-down, 'smart' workplaces and digitally networked factories have been able to produce enough to supply dealers 'justin-time', and can change outputs on short notice to meet changing demands and allow product innovation. Low level assembly line or service jobs have been replaced by technology or outsourced to cheaper part-time workers, who find themselves seeking employment in a rapidly expanding service economy characterised by unstable, less secure work opportunities that generally offer lower wages even to those with higher education and experience (Kalleberg 2000). This has resulted in the 'hollowing out of work' in industrialised countries: at the top are the highly skilled, very highly paid jobs that steer the networked digital economy; at the bottom are the unstable, low-wage, low-skill jobs; and in the middle is the systematic demise of mid-level, middle-wage, 'blue collar' jobs.

From the 1980s onwards, digital connectivity has distributed the workplace across localities, with smaller work teams supplemented by contracted temporary staff. In the OECD countries, from about 1985 to 1995 , between one-third and one-half of the total labour force comprised temporary staff (Carnoy and Castells 2001). After 1975, the typical household employment profile became one of dual earners or single parents rather than the traditional male breadwinner (Potter 2003). The shift away from 'permanent', full-time jobs in stable businesses has eroded workers' identification with their 
workplace or trade union, and the relationship of workers to supervisors has become individualised. Freelancers and consultants have focussed increasingly on promoting themselves in order to sell their services, robbed of the 'traditional' workplace identity that had been the norm for more than a century and from the social networks that had provided economic security (Carnoy and Castells 2001). As automation has increased and as the labour market has become diversified and polarised, trade unions have struggled to address the divergent needs of workers; the collective identity of a working class and hence the power of trade unions has declined. However, the labour market has remained the conduit through which global poverty is shaped.

The fundamental social transformations of the 3IR have been enormously complex, permeating aspects of identity and diversity, social inclusion or exclusion, urban life, media and consumer culture, and the cohesion of families. As Robin Cohen puts it: 'All the dimensions of globalization - economic, technological, political, social and cultural ... [have coalesced], each reinforcing and magnifying the impact of the others' (2006: 183). Castells (1999, 2000) suggests that networks constitute the social morphology of the information age. These networks have no central organising principle, but have had an identifiable social hierarchy (Beck 2000; Castells 2000):

- Global elites, very well-paid but typically 'time-poor'. They live in wealthy enclaves, linked electronically on decisionmaking networks. They meet only for major strategising.

- Precariously employed skilled people whose lives oscillate between intense work and 'downtime'. They live in 'the suburbs', distanced from the masses and connected digitally to workplaces and metropolitan hubs.

- The working poor, often relying on 'piece jobs' or shortterm employment. They live in social housing, within reach of work centres and transport systems. While digitally connected via cell phones, they do not use this connectivity in their work.

- A growing unemployed underclass whose lives are directionless but 'time-rich'. They live on the margins, in inner city slums or informal settlements on the outskirts of cities. 
It strikes me that one way to broadly characterise the central contradiction of the globalised information society is this: half the people do twice as much work as they should and the other half cannot find jobs (the maths is perfect). In 1996, in Denmark, France, Germany, Japan, Britain and the United States almost 35 million people were jobless and even more were in insecure, low-wage jobs while in most developing countries 'poverty [was] widespread and chronic underdevelopment [meant] that millions of workers [were] destined to eke out a living in physically onerous, low-productivity tasks' (Härtl 1996: 3).

Perhaps the most significant social tensions brought about by the 3IR have been those between cultural uniformity and diversity. Cultural uniformity was soon known as 'McDonaldisation': scores of people everywhere, eating the same fast food, wearing the same brands and connected together in social media friendships by means of the same rules of personal display. Cultural diversity, on the other hand, has from the 1990s been increasingly generated by means of the Internet. Information technology rapidly provided means - notably blogging - for 'the existence of fresh kinds of highly-informed, autonomous communities that coalesce around local lifestyle choices, global political demands, and everything in between' (Kahn and Kellner 2004: 89).

The complex, fundamental change that characterises this period makes it quite clear that it meets the criteria to be considered an industrial revolution:

1. Technological revolution: the Internet of digitally networked, global information technology;

2. Transformation of the labour process: the individualisation and global dispersion of work;

3. Changing work relations in the workplace: the hollowing out of the workforce; the growth of the service sector;

4. Changing community and social relations: the emergence of contradictory cultures of uniformity and diversity; and

5. International/global transformations: the international redistribution of production; the structural deepening of the gulf between the richer and poorer regions of the world.

Together, in all of their complexity, these phenomena came to be known as 'globalisation'. This is the defining reality of the 3IR. 


\section{Technologies Held up as Evidence of a Fourth Industrial Revolution}

Each of the three industrial revolutions discussed above has been characterised by radical technological innovation. If the 4IR is now upon us, as so many claim, then there should be clear evidence of fundamentally new innovation that is not simply an accelerated evolution of the technologies of the 3IR.

There is no shortage of technologies held up as evidence of the 4IR. On closer inspection, however, these claims bear little weight. To investigate this issue, I conducted a search using the term 'fourth industrial revolution' on the Google and Google Scholar search engines (3IR technologies). In most sources, five to ten 'technologies' were listed and claimed to be merging in a way that constituted a new industrial revolution. I compiled a list of these terms until the data appeared to be saturated. I categorised the fifty-nine terms (amongst which are many synonyms) as shown in Table 1.

Fourteen of the terms are not, in fact, technologies. Five of these merely describe groupings of technologies. But two-digitalisation and artificial intelligence - are often spoken of as 'technologies', which is misleading. Digitalisation is a sociological concept that refers to the way in which most domains of social life are transformed around the digital technology (i.e. 3IR) infrastructure that is now at the centre of society. Artificial intelligence (AI) is a field of knowledge and research which originated in the 1950s that seeks to build artificial animals and humans; various technologies apply AI knowledge, most notably machine learning.

The thirty-eight terms on the right refer to technologies developed before the new millennium - during the period that was undisputedly the 3IR. The new innovations in the first column may or may not be 'revolutionary' in themselves, but they exist at this point only as thought experiments or very early stages of prototype development and have not yet had a social impact. With regard to 'nanotechnology', the most interesting contemporary developments in this area are indeed thought experiments.

The terms in bold typeface were by far the most frequently mentioned in the sources that were reviewed. We are used to hearing proponents of the 4IR name these technologies in their efforts to convince us that the 4IR has begun. While many of the technologies 
Table 1. Terms Claimed to Be '4IR Technologies' in Internet Searches

\begin{tabular}{|c|c|c|}
\hline \multirow{2}{*}{$\frac{\text { New Innovations (7) }}{\text { Autonomous vehicles }}$} & \multicolumn{2}{|c|}{ Technologies Originating in the 3IR (38) } \\
\hline & 3D Printing & Intelligent machines \\
\hline Molecular informatics & Automation & Local game-saving \\
\hline Nanotechnology & Big Data & Machine-learning platforms \\
\hline Quantum computing & Internet of Things & Mixed reality \\
\hline Self-driving motorcars & Machine Learning & Natural language generation \\
\hline Semantic web & Robotics & Natural language processing \\
\hline \multirow[t]{2}{*}{ Socio-technology } & 3D graphics & Robotic process automation \\
\hline & $5 \mathrm{G}$ technology & Robots \\
\hline Not Techologies (14) & $\begin{array}{l}\text { Advanced wireless } \\
\text { technologies }\end{array}$ & $\begin{array}{l}\text { Smaller and more powerful sensors } \\
\text { Smartphones }\end{array}$ \\
\hline Artificial Intelligence & Analytics / big data & Speech recognition \\
\hline Digitalisation & analytics & Techno-materials \\
\hline Organising frames (5) & Augmented reality & Virtual reality \\
\hline Ambient computing & Autonomous safety robots & Voice-activated virtual assistants \\
\hline Converging technologies & Bioinformatics & \\
\hline Fusion of technologies & Biotechnology & \\
\hline Merging technologies & Blockchain & \\
\hline Ubiquitous computing & Cloud computing & \\
\hline Others (7) & Computer-integrated & \\
\hline Big bang disruptions & manufacturing & \\
\hline Factories of the future & Cyber-physical systems & \\
\hline Genetics & Deep learning platforms & \\
\hline Genomics & Digitisation & \\
\hline Industry 4.0 & Drones & \\
\hline Manufacturing 2.0 & Gene sequencing & \\
\hline Utility computing & Genetic engineering & \\
\hline & HTML5 & \\
\hline
\end{tabular}

in the 3IR column in Table 1 are being developed in exciting, complex ways right now, they are all rooted in the digital revolution that commenced in the previous century. It is worth considering the most 'popular' of these in more detail.

The Internet of Things (IoT) is a system of networked mechanical and digital devices with the ability to transfer data amongst themselves without human intervention. The core technology of the IoT is the Internet, which was created in 1969 and expanded globally in the WWW. Analogue to digital (ADC) and digital to analogue (DAC) converters, which link mechanical devices via sensors and actuators into the IoT, first appeared in the 1960s (Kester 2005). The first IoT was reputedly tested in the early 1980s, when techies 
at Carnegie Mellon University installed micro-switches in a vending machine to check cooldrink availability from their desks (Teicher 2018). Perhaps the most significant piece of technology in the evolving IoT is Trumpet Winsock, invented in 1994, which made it possible to attach PCs to Internet networks (Zittrain 2008).

In much the same vein, big data storage and associated analytics are technologies that enable a massive coming together of information in extensive, global networks (Arutyunov 2012; Hurwitz et al. 2013). While the amount of data that can be handled is unprecedented, the technologies were developed in the 3IR and have evolved over time. Judith Hurwitz and colleagues (2013) write:

It would be nice to think that each new innovation in data management is a fresh start and disconnected from the past. However ... most new stages or waves of data management build on their predecessors. . . Data management has to include technology advances in hardware, storage, networking, and computing models such as virtualization and cloud computing. ... The data management waves over the past five decades have culminated in where we are today: the initiation of the big data era (2013: 10-11).

In the $1950 \mathrm{~s}$, the first computer systems stored data on magnetic disks. This was followed by the silicon chip in 1961. In the 1970s, database structures were developed and grew more complex. By the 1990 s, the data warehouse was developed. And in the new millennium, cloud computing evolved as warehousing that was taken offsite (Arutyunov 2012). Cloud computing brings together diverse data (and also provides complex computing off-site), but this pairing of data, not the evolving technology, is what is distinctive of the twenty-first century. Big data has a long history but a short past!

Robotics looms large in science-fiction-like evocations of a 4IR. However, robots are actually very mechanical. The first one was built in 1961; by 2000, there were 750000 , and now there are 2.7 million industrial robots deployed in factories around the world with the largest number in China and the most rapid increase in India (IFR 2020). Most of these are still 'unintelligent' mechanical arms, but 'learning robot' technology started to develop in the 1970s. WABOT-1, the first anthropomorphic robot, appeared in Japan in 1973, sparking research on bipedal walking functions in robots into the 1980s (Takanishi 2019). Robots had to be tediously hand-programmed for every task until about the late 1970s; to overcome this, 
robotics needed machine-learning technology. Increasing demand in the 1980s for robots capable of identifying parts from random selections, or maintaining 'positional accuracy' when objects shift about on assembly lines (Yerkey 1984), brought machine learning into robotics.

Machine learning refers to the capacity of computers to learn 'from experience' by improving their information-processing ability over time by running algorithms to access and process data. Deep learning, an evolution of machine learning, creates an 'artificial neural network' that can learn and make decisions on its own. This technology dates to computing in the 1950s with the first artificial neural network able to learn patterns and shapes. Research on machine learning exploded in the 1980s. Advances in very-largescale integration technology made it possible to build hardware containing thousands of processors; neural networks were explored as a way to distribute computation over a large number of processing units running in parallel (Alpaydin 2016).

The convergence of robotics and machine learning in the 1990s was a significant technological breakthrough of the 3IR. Algorithms in robots enabled 2D and 3D object searches and 'object learning', where a robot makes and acts on predictions derived from probabilistic reasoning. Walter Van de Velde describes learning robots as 'able to learn for themselves what is best for them, without their designers having to figure it all out beforehand', and suggests that by the 1990s such robots were 'more than [just] programmatic talk' (1993: 1). The most pervasive intelligent robots today are the chatbots in cell phones - the latest phase in the evolution of natural language processing dating back to the 1960s. Let us also not forget that in 1997 the IBM computer Deep Blue beat the world chess champion.

$3 D$ printing, or additive manufacturing, is a family of technologies that use photopolymerisation to build solid objects from digital models. The Japanese inventor, Kodama, created a solid object by using ultraviolet light to harden polymer plastic in 1980. In the mid-1980s, stereolithography (SLA) was developed using a laser beam focussed on light-reactive 'resin', along with laser sintering (SLS), using fused layers of powdered polymer. This was followed in 1989 by fused deposition modelling (FDM), which has been dubbed 'desktop 3D printing' because it is the most commonly used 
form of the technology today. SLA, SLS, and FDM make up the history of $3 \mathrm{D}$ printing and clearly constitute an enduring, innovative technology of the 3IR.

All of these technologies represent the gradual evolution of the defining technological transformations of the 3IR: none is a radical, ground-breaking invention of the new millennium. To be fair, many of the prophets of the 4IR make the point that it is not so much individual technologies in their own right that constitute a technological revolution, but rather the unprecedented converging of technologies.

So for Klaus Schwab, the 4IR is evident in 'the staggering confluence of emerging technology breakthroughs, covering wideranging fields such as artificial intelligence, robotics, the internet of things, autonomous vehicles, 3D printing, nanotechnology, biotechnology, materials science, energy storage and quantum computing, to name a few' (2016: 7). For Tshilidzi Marwala (2020), the 4IR is 'the current that blurs the lines between the physical, digital and biological spheres through AI, automation, biotechnology, nanotechnology and communication technologies ... contrary to the earlier industrial revolutions, 4IR is based not on a single technology, but on the confluence of multiple developments and technologies'. For Devon McGinnis (2018), it is a 'fusion of advances in artificial intelligence, robotics, the Internet of Things, 3D printing, genetic engineering, quantum computing, and other technologies' (all my emphases).

Marwala is simply wrong when he suggests that each of the earlier industrial revolutions was based on a single technology. It was the transatlantic convergence of the cotton gin, the spinning mule, the mechanical loom and Watt's steam engine that created the technological revolution that contributed to the 1IR. In the 2IR, economic historians tend to consider the systematically planned convergence of technologies in the assembly lines of the 2IR factory to be the decisive breakthrough of modern industrial society (Jevons 1931; Schön 2007). In the 3IR, the Internet was the technology of the convergence of technologies that brought about the digital revolution. The consequences of this continued to unfold on a trajectory, bringing new mergings of technologies - such as the IoT.

Technologies have been converging continuously throughout history. While convergences that are possible today in the digital 
era can easily seem revolutionary, there is little evidence to support the notion that the rapid technological change occurring now is fundamentally new in character. This is not to say that there are no technological innovations occurring during this period that are challenging the status quo of the 3IR within their own context. One example that is without doubt revolutionary - and also represents a confluence of technologies - is the first real-life, bionic 'shadow hand' developed in brain robotics. It amplifies and translates electrical impulses from the human nervous system into digital information, allowing a person to control the robotic hand (McNamara 2020; Wits University 2019). This truly transcends the ADC and DAC converters of the 3IR. Other ground-breaking technological initiatives are underway in research institutions around the world. However, there is sparse evidence of a socially pervasive, 'grand' convergence of new technologies that transcends the digital revolution in some way. Like the period after the Second World War, technology is currently experiencing accelerated change, but not transformation.

\section{There Is No Fourth Industrial Revolution}

Apart from the question of how revolutionary current technological developments are, if the 4IR has arrived, then we should find evidence of deep transformation of the labour process, labour relations, social life and international socio-economic relations, as was the case in the 1IR, 2IR and 3IR. An investigation shows that change in these areas, too, is consistent with the 3IR, with no overturning of the current order in sight.

The international hollowing out of the labour market characteristic of the 3IR continues, deepened by further automation of factories and businesses (OECD 2019a, 2019b). The proportion of middle-skill jobs in OECD countries has dropped from 42 percent in 2000 to 32 per cent, while high-skill employment has increased some 8 per cent and low-skill 2 per cent (OECD 2020a). The OECD (2019a) predicted (prior to the COVID-19 pandemic) that this 'hollowing out' would continue, with 14 per cent of middle-class jobs expected to disappear as a result of automation in the next two decades and another 32 percent likely to change radically as tasks 
are automated. While employment in services is likely to increase concomitantly, this will be largely 'lower-quality and precarious jobs' (OECD 2019a: 3). In non-OECD countries (such as Brazil, Russia and countries across Africa) the situation is even more stark - for example, in South Africa, less than one-third of the workforce is in mid-skill jobs (OECD 2019b) and about one-third of 14 million jobs face an 80 per cent plus probability of becoming automatable (Le Roux 2018). Against this backdrop, work tends to be increasingly individualised and atomised: either globally dispersed for highly skilled experts or localised in mundane service sector activities. The fracturing of occupational identities associated with the 3IR continues.

One consequence of individualisation and the transient 'team work' that goes with it is the breakdown of collective solidarity in the workplace and beyond (Huws 2014; Visser 2019a). Precarious work is inherent in the 3IR labour process, and workers are disconnected 'from [their] structural and traditional position within the institutional framework of labour' (Allvin 2004: 23). In this situation, the decline of the influence of and membership in trade unions continues into the twenty-first century. In countries with deep, long-standing trade union traditions, the continuing decline in membership is dramatic: in the United States, for instance, unions represented 20 per cent of workers in 1983, but represent only 10 per cent in 2020 (Rosenberg 2020); in Britain, similar decline is evident from the 1980s to the present (Figure 2). OECD statistics in general reveal a decline in union density rates - the proportion of union members amongst employees - from 30 per cent in 1985 to just 16 per cent in 2019 (OECD 2020b).

These declines are most pronounced in 'advanced industrial countries' - the global industrial nexus tracked historically through this article. However, in poorer, 'developing countries' only a minority of workers have formal employee status, which inflates union density rates (Visser 2019b). In South Africa, for example, unions decline because they rely on traditional models of organising to represent the interests of permanent workers, and neglect the struggles of increasing numbers of precarious workers (Webster and Forrest 2019). Generally speaking, the hollowing out process ramifies globally into the 'disappearance of the working class as a collective social force, accompanied by the decline of a socialist 


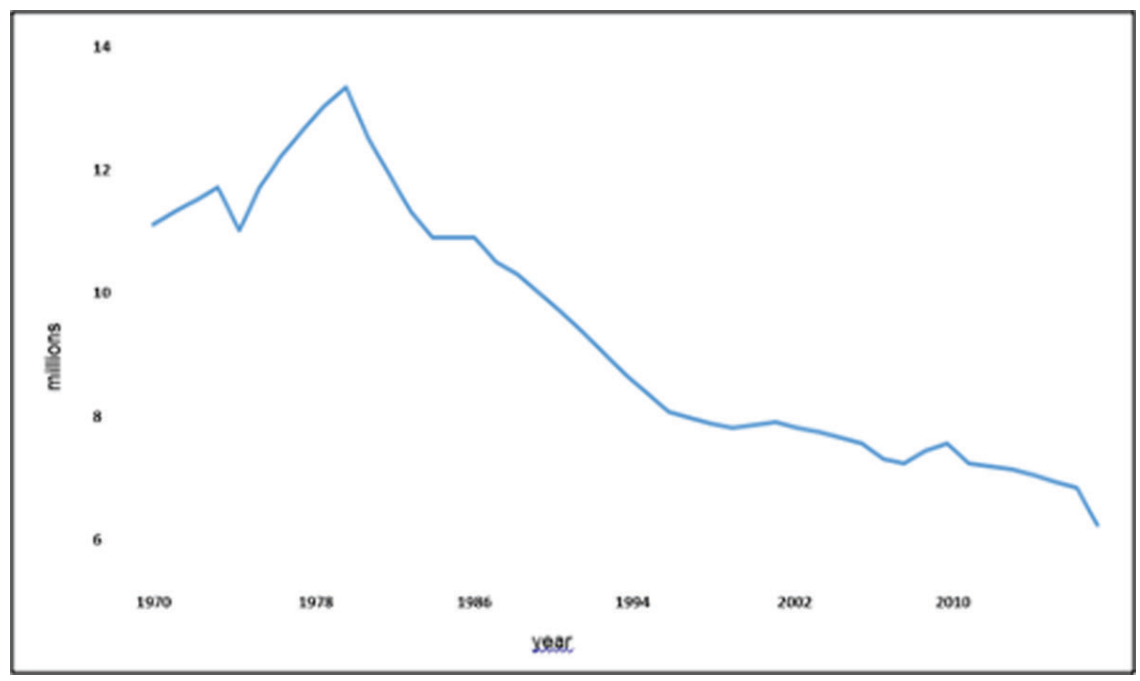

Figure 2. Declining Trade Union Membership in Britain (after Topping 2017)

culture' and progressive social movements (Virdee and McGeever 2018: 1815).

Socially, a broader hollowing out of the middle classes persists in a dialectical relationship with the context of labour. As Geoff Dow (2017) points out, the digital economy generates the social phenomena associated with unemployment at a much faster rate than it generates income, wealth and prosperity. Castells' (1999) 'doubleedged sword' of the 3IR - economic prosperity on the one hand, rising urban poverty, inequality and environmental degradation on the other - is extremely sharp. The erosion of the 'political and cultural middle' continues as intra-urban inequalities and residential segregation in large cities develop in a reciprocal relationship with digital inequality (Gilbert 2010; Nijman and Wei 2020; UN 2020). The digital economy, 'for all its vigor, growth and contributions to aggregate prosperity, has forged new spatial inequalities in and between cities ... disparities have grown, suburbs have been resorted into a wide array on the basis of class and race' (Nijman and Wei 2020: 2).

Widespread disillusionment with this growing inequality threatens the basic legitimacy of political systems. There is general consensus amongst analysts, for example, that this deep social crisis explains 
the support for Trump and Brexit witnessed in recent times: 'Thumbing their noses at party establishments, [voters] have repudiated the arrangements that have been hollowing out their living conditions for the last 30 years' (Fraser 2016: 281). This 'left behind' identity, and the loss of faith in institutions, goes a long way toward explaining the growth of socio-cultural politics uncomfortable with the social status quo (Wahl-Jorgensen 2018; Virdee and McGeever 2018). The 3IR's contradictory patterns of social life continue, with various expressions of nationalism, fundamentalism and chauvinism clashing (or sometimes cohering) with various expressions of group identity, internationalism, diversity and global solidarity. We see this, for example, in intensified expressions of solidarity carried on the Internet, such as \#BlackLivesMatter, \#womenpower, \#gaypride, \#BDS, \#jewsforjustice and \#rhodesmustfall.

Finally, globally, the 3IR pattern of the marginalisation of the South continues, whether by continued offshoring, by onshoring back to automated factories, or simply by discarding the "people (or places) who are not, or are not any longer, considered valuable, even if they are still physically there' (Castells 1999: 9). All the evidence of offshoring and foreign outsourcing suggests a deepening of the exploitative patterns of the 3IR that is likely to continue for some time into the future (ILO 2019). The terrain is like a cynical gaming environment in which multinational corporations continually shift production and business systems around the globe in search of the cheapest labour and infrastructure costs.

The offshoring trends that began in motorcar and garment factories in the later twentieth century have continued in an expanded range of industries until the present. Furthermore, there is an emerging pecking order, in which high-skill operations continue to be shifted to the 'dominant players' - like China, India, Indonesia and Eastern Europe - and low-skill operations are offshored/ outsourced to poorer countries. Western European multinationals now frequently offshore production to countries like Poland and Hungary (Warda 2013). Rising labour costs in China and India have led to a steady shift of production to low-cost suppliers in countries like Bangladesh, Cambodia, Nicaragua and Vietnam and, most recently, to Ethiopia and other African countries (ILO 2019). Ironically, even as they continue to be destinations of choice for high-skill services, China and India are themselves offshoring 
their garment factories to Africa. There is an increasing view that African countries, as their infrastructures improve and if their cheap labour costs are maintained, 'may be set for recognition, with Ghana, Mauritius and Egypt already emerging as ... major offshoring destinations' (Omoju 2017: 103; see also Anon 2018; and Lago 2019). The situation is a destructive paradox for the poorest countries in the world: Ethiopia, for example, the twentieth poorest (World Bank 2020), is forced to provide the cheapest labour in the world in order to compete in the offshoring market. Multinational clothing factories now offshore to Ethiopia to manufacture favourite fashion brands and employ the lowest paid garment workers in the world (Barrett and Baumann-Pauly 2019). This deep exploitation is characteristic of the digital 3IR economy.

These realities relate to globalisation and the tensions between those who drive and benefit from it and those who are marginalised by it and often resist it. None of the five criteria taken from the 1IR to identify a new industrial revolution are met in our current reality. The basic argument that has been developed here is as follows: (i) very few of the technologies claimed to be 4IR are more than just continuous, albeit increasingly complex, versions of 3IR technologies; and (ii) in any event, there is little evidence of the major social, cultural and geopolitical changes based on a confluence of these technologies that would constitute a 4IR.

\section{'Industrial Revolution' as Ideology}

Why, then, do so many people - including prominent ideologues like Schwab (2016) and Marwala (2020) - claim that the fourth industrial revolution is upon us if it is not? The explanation, I believe, is the force that this ideology can wield to advance the interests of the powerful:

Globalization contains important ideological aspects in the form of politically charged narratives that put before the public a particular agenda of topics for discussion, questions to ask, and claims to make. . . The social forces behind these competing accounts of globalization seek to endow this concept with norms, values, and meanings that not only legitimate and advance specific power interests but also shape the personal and collective identities of billions of people. (Steger 2009: vii) 
It is not within the scope of this article to carry out a detailed analysis of how the ideology of the 4IR has emerged and the extent to which it has developed, but it seems to have arisen because the digitalised, information-driven, international order is in trouble. As Johan Muller recently cautioned, current world events 'have not been kind to globalization' (or, by implication, to the 3IR):

[By 2016] the optimistic message that globalization could be a powerful positive force if it was managed correctly ... had been mauled in dramatic fashion, though some would say its dark side could have been predicted if not averted had we paid more careful attention. What is unequivocally clear is that a wave of anti-technological modernization and anti-globalization is sweeping through the traditional West, and a virulent populism is everywhere on the rise. (Muller 2017: 17)

Castells' (1999) vision that the network society could develop into 'a virtuous circle of development' faces increasing evidence to the contrary. Countries on the periphery of the international economic consensus face 'a downward spiral of underdevelopment' (Castells 1999: 4), and those at its centre (the nations that have been established as the 'global industrial nexus' since 2IR) find their position challenged by local, anti-global, populist political agendas in their own countries. Portraying rapid technological development as a bold, new industrial revolution is a far stronger strategy for those seeking to mobilise political, social and economic forces to secure their position of dominance against these threats than a whimpered appeal that we revive and repair the 3IR in which we actually continue to live. Thus, the 'myth of the fourth industrial revolution' is born: it is an ideological strategy driven by the World Economic Forum (Schwab 2016) and by governments which has shaped economic interventions focussed on the language of a 4IR.

None of this is to suggest that some future industrial revolution is not in the offing. The suggestion in this article is that a putative, extant 4IR is a myth which functions to shore up and even resuscitate the flagging economic systems of globalisation. However, the twenty-first century has seen growing debate about a possible new industrial revolution, in which a transformation in the way we work can be to the overall benefit of the human species and, in terms that 
have been emphasised in the current argument, to Africa (Moll 2020; Morgan 2018). Technology will no doubt continue to alter work, and lead to new varieties of work. Such a revolution will be rooted in the technological breakthroughs associated with the digitally networked society, but it must also meet the broader social, cultural and geopolitical transformations to constitute a revolution (in the terms adduced in this article). There is in an extensive 'end-of-work' literature that is pushing the boundaries of this debate (see, inter alia, Beck 2000; Gorz 1999; Rifkin 1995; and Morgan 2018, 2019). Jeremy Rifkin (2011), for example, envisages a coming industrial revolution (he sees it as the full fruition of the 3IR) in which the convergence of green energies and the IoT will produce fundamental socio-economic transformation. Ulrich Beck (2000) and André Gorz (1999) both envisage a social transformation, including a transformation of work, based on a guaranteed minimum wage for all. These are visions of a 4IR that may or may not happen. If it does, it needs to transcend the current 4IR myth that we can so easily take for granted.

\section{Acknowledgements}

My thanks go to the anonymous reviewers of this article, and to my colleagues S'tha Ndlovu, Barry Dwolatsky, Yael Shalem, Lynne Slonimsky and Reuben Dlamini, for helpful comments on earlier drafts of this article.

Ian Moll is a lecturer in the Division of Educational and Engineering Technology in the School of Education, University of the Witwatersrand. His interests are in the network society, cognitive psychology and e-learning. E-mail: ian.moll@wits.ac.za

\section{Note}

1. The periodisation of a social transformation like an industrial revolution is a debatable historical judgement in itself. Arnold Toynbee (1884) first dated the 1IR from 1760 to 1840 . The dates used throughout this article are rough averages from across all sources consulted. 


\section{References}

Allen, R. C. 2006. The British Industrial Revolution in a Global Perspective. Cambridge: Cambridge University Press.

Allen, R. C. 2019. 'Class Structure and Inequality during the Industrial Revolution: Lessons from England's Social Tables, 1688-1867'. The Economic History Review 72 (1): 88-125. doi.org/10.1111/ehr.12661. Allvin, M. 2004. 'The Individualisation of Labour'. In C. Garsten and K. Jacobsson (eds), Learning to Be Employable. London: Palgrave Macmillan, 23-41.

Alpaydın, E. 2016. Machine Learning: The New AI. Cambridge, MA: MIT Press. Anon. 2018. 'Why Outsourcing Technology Services into Africa Is on the Rise'. Impact IT, 24 August. http:/www.impactit.co.za/why-outsourcingtechnology-services-into-africa-is-on-the-rise/.

Arutyunov, V. V. 2012. 'Cloud Computing: Its History of Development, Modern State and Future Considerations'. Scientific and Technical Information Processing 39 (3): 173-178. doi:10.3103/S0147688212030082.

Barrett, P. M. and D. Baumann-Pauly. 2019. Made in Ethiopia: Challenges in the Garment Industry's New Frontier. New York University: Stern Centre for Business and Human Rights. https://humanrights.wbcsd.org/project/made-inethiopia-challenges-in-the-garment-industrys-new-frontier/.

BBC. n.d. 'Importance of the Slave Trade to the British Economy'. https://www. bbc.co.uk/bitesize/guides/zc92xnb/revision/4.

Beck, U. 2000. The Brave New World of Work. Cambridge: Polity Press.

Beckert, S. 2014. Empire of Cotton: A Global History. New York: Alfred A. Knopf.

Berlin Conference. 1885. 'General Act of the Berlin Conference on West Africa, 26 February 1885'. South African History Archives. http://www.saha.org.za/.

Braverman, H. 1998. Labor and Monopoly Capital: The Degradation of Work in the Twentieth Century. New York: Monthly Review Press.

Bythell, D. 1983. 'Cottage Industry and the Factory System'. History Today 33 (4): 17-23. https://www.historytoday.com/archive/cottage-industry-andfactory-system.

Cannadine, D. 1984. 'The Present and the Past in Britain's Industrial Revolution, 1880-1980'. Past and Present 103: 131-172. doi:10.1093/ past/103.1.131.

Carnoy, M. and M. Castells. 2001. 'Globalization, the Knowledge Society, and the Network State: Poulantzas at the Millennium'. Global Networks 1 (1): 1-18. doi:10.1111/1471-0374.00002.

Castells, M. 1999. 'Information Technology, Globalization and Social Development'. Discussion Paper No. 114. Geneva: United Nations Research Institute for Social Development.

Castells, M. 2000. The Rise of the Network Society. Chichester, UK: Wiley Blackwell. 
Castells, M. and A. Portes. 1989. 'World Underneath: The Origins, Dynamics, and Effects of the Informal Economy'. In A. Portes, M. Castells and L. A. Benton (eds), The Informal Economy: Studies in Advanced and Less Developed Countries. Baltimore: Johns Hopkins University Press, 11-41.

Cohen, R. 2006. Migration and Its Enemies: Global Capital, Migrant Labour and the Nation-State. Aldershot, UK: Ashgate.

Coleman, D. C. 1992. Myth, History and the Industrial Revolution. London: Hambledon.

Dattel, E. 2009. Cotton and Race in America (1787-1930): The Human Price of Economic Growth. Chicago: Ivan Dee.

Dow, G. 2017. 'Political Tragedy and Disillusionment Today'. Social Alternatives 36 (1): 34-36. https:/www.questia.com/library/p436410/socialalternatives/i4192325/vol-36-no-1-2017.

Engelberger, J. F. 1985. 'Historical Perspective of Industrial Robots'. In S. Y. Nof (ed.), Handbook of Industrial Robotics. New York: John Wiley and Sons, 3-8.

Engels, F. (1845) 1998. Condition of the Working Class in England. Marxists. org. https://www.marxists.org/ archive/marx/works/1845/condition-workingclass/ch02.htm.

Falkus, M. 1987. Britain Transformed: An Economic and Social History 17001914. Oxford: Alden.

Fanon, F. O. (1961) 2004. 'The Trials and Tribulations of National Consciousness'. In The Wretched of the Earth. New York: Grove, 97-144.

Frank, A. G., 1971. Capitalism and Underdevelopment in Latin America. Harmondsworth, UK: Penguin.

Fraser, N. 2016. 'Progressive Neoliberalism versus Reactionary Populism: A Choice that Feminists Should Refuse'. Nordic Journal of Feminist and Gender Research 24 (4): 281-284. doi:10.1080/08038740.2016.1278263.

Freeman, C. and F. Louçã. 2001. As Time Goes By: From the Industrial Revolution to the Information Revolution. Oxford: Oxford University Press.

Gilbert, M. 2010. 'Theorizing Digital and Urban Inequalities'. Information, Communication and Society 13 (7): 1000-1018. doi:10.1080/13691 18X.2010.499954.

Gorz, A. 1999. Reclaiming Work: Beyond the Wage-Based Society. Cambridge: Polity Press.

Greenwood, J. 1999. 'The Third Industrial Revolution: Technology, Productivity, and Income Inequality'. Federal Reserve Bank of Cleveland Economic Review 35 (2): 2-12. https://www.clevelandfed.org/en/newsroomand-events/publications/discontinued-publications/economic-review/1999economic-review/er-1999q2-the-third-industrial-revolution.aspx.

Griffiths, I. 1986. 'The Scramble for Africa: Inherited Political Boundaries'. The Geographical Journal 152 (2): 204-216. https:/www.jstor.org/ stable/634762.

Haines, C. G. and W. B. Walsh. 1941. The Development of Western Civilization. New York: Henry Holt. 
Hall, P. 2014. Cities of Tomorrow: An Intellectual History of Urban Planning and Design Since 1880. 4th ed. New York: Wiley.

Härtl, G. 1996. 'Debunking Myths: World Employment 1996/97'. ILO World of Work 18 (3). https://www.ilo.org/wcmsp5/groups/public/---dgreports/--dcomm/documents/publication/dwcms_080637.pdf.

Hill, T. P. 1987. 'On Goods and Services'. Review of Income and Wealth 23 (4): 315-338. doi:10.1111/j.1475-4991.1977.tb00021.x.

Hobsbawm, E. J. 1962. The Age of Revolution: Europe 1789-1848. London: Weidenfeld and Nicolson.

Hobsbawm, E. J. 1989. The Age of Empire 1875-1914. New York: Vintage Books.

Hobsbawm, E. J. 1995. The Age of Extremes: The Short Twentieth Century 1914-1991. London: Abacus.

Hobsbawm, E. 1997. 'From Social History to the History of Society'. In On History. London: Abacus, 94-123.

Humphries, J. 2013. 'Childhood and Child Labour in the British Industrial Revolution'. The Economic History Review 66 (2): 395-418. doi:10.1111/ j.1468-0289.2012.00651.x.

Hurwitz, J., A. Nugent, F. Halper, and M. Kaufman. 2013. Big Data for Dummies. Hoboken, NJ: Wiley.

Huws, U. 2014. Labor in the Global Digital Economy. New York: Monthly Review Press.

IFR (International Federation of Robotics) 2020. 'IFR Presents World Robotics Report 2020'. Press release, 24 September, Frankfurt. https://ifr.org/ifr-pressreleases/.

ILO (International Labour Organisation). 2019. 'The Future of Work in Textiles, Clothing, Leather and Footwear', Working Paper No. 326. Geneva: ILO Sectoral Policies Department.

Jevons, H. S. 1931. 'The Second Industrial Revolution'. The Economic Journal 41 (161): 1-18. doi:10.2307/2224131.

Kahn, R. and D. Kellner. 2004. 'New Media and Internet Activism: From the "Battle of Seattle" to Blogging'. New Media and Society 6 (1): 87-95. doi:10.1177/1461444804039908.

Kalleberg, A. L. 2000. 'Nonstandard Employment Relations: Part-time, Temporary and Contract Work'. Annual Review of Sociology 26: 341-365. doi:10.1146/annurev.soc.26.1.341.

Keane, J. 2014. 'The Governance of Global Value Chains, Upgrading Processes and Agricultural Producers in Sub-Saharan Africa'. In T. Fukunishi (ed.), Delivering Sustainable Growth in Africa: African Farmers and Firms in a Changing World. Basingstoke, UK: Palgrave Macmillan, 23-53.

Kennedy, P. 1993. Preparing for the Twenty First Century. New York: Random House.

Kester, W. (ed.). 2005. The Data Conversion Handbook. Amsterdam: Elsevier. 
Kondratieff, N. D. 1935. 'The Long Waves in Economic Life'. Review of Economics and Statistics 17 (6): 105-115. http://www.jstor.org/ stable/1928486.

Lago, C. 2019. 'The Culture of Outsourcing in Africa'. CIO, 2 September. https://www.cio.com/article/3432198/the-culture-of-outsourcing-in-africa. html.

Lange, M., J. Mahoney and M. vom Hau. 2006. 'Colonialism and Development: A Comparative Analysis of Spanish and British Colonies'. American Journal of Sociology 111 (5): 1412-1462. doi:10.1086/499510.

Le Roux, D. B. 2018. 'Many South African Jobs Could Soon Be Automated, and the Country Isn't Prepared'. The Conversation, 17 July. https:// theconversation.com/many-south-african-jobs-could-soon-be-automated-andthe-country-isnt-prepared-99689.

Levy, D. L. 2005. 'Offshoring in the New Global Political Economy'. Journal of Management Studies 42 (3): 685-693. doi:10.1111/j.14676486.2005.00514.x.

Marglin, S.A. and J. B. Schor. 1992. The Golden Age of Capitalism: Reinterpreting the Postwar Experience. Oxford: Oxford University Press.

Marwala, T. 2020. 'Covid-19 Has Forced Us into the Fast Lane of the 4IR Super-Highway’. Daily Maverick, 28 May. https:/www.dailymaverick.co.za/ opinionista/2020-05-28-covid-19-has-forced-us-into-the-fast-lane-of-the-4irsuper-highway/.

Marx, K. and F. Engels. (1848) 2010. Manifesto of the Communist Party. Marxists Internet Archive. https:/www.marxists.org/archive/marx/works/ download/pdf/Manifesto.pdf.

Maulik, S. and S. D. Patel. 1997. Molecular Biotechnology: Therapeutic Applications and Strategies. New York: Wiley.

McLennan, G. 1981. 'The "Labour Aristocracy" and "Incorporation": Notes on Some Terms in the Social History of the Working Class'. Social History 6 (1): 71-81. doi:10.1080/03071028108567495.

McGinnis, D. 2018. 'What Is the Fourth Industrial Revolution'? Salesforce, 27 October. https:/www.salesforce.com/blog/2018/12/what-is-the-fourthindustrial-revolution-4IR.html.

McNamara, A. 2020. 'Nerve Interface Technology Allows Amputees to Use Thought to Move Bionic Limb'. Science Focus, 5 March. https://www. sciencefocus.com/news/nerve-interface-technology-allows-amputees-to-usethought-to-move-bionic-limb/.

Milberg, W. and D. Winkler. 2009. 'Globalization, Offshoring and Economic Insecurity in Industrialized Countries'. DESA Working Paper No. 87 ST/ ESA/2009/DWP/87. New York: United Nations Department of Economic and Social Affairs.

Mokyr, J. 1998. 'The Second Industrial Revolution, 1870-1914'. In Valerio Castronovo (ed.), Storia dell'economia Mondiale. Rome: Laterza Publishing, 219-245. 
Moll, I. 2020. 'The First Three Industrial Revolutions Stripped Africa Bare - It's Hard to See Why the Fourth Would Be Any Different'. Daily Maverick, 20 August. https://www.dailymaverick.co.za/author/ian-moll/.

Morgan, J. 2018. 'Species Being in the Twenty-First Century'. Review of Political Economy 30 (3): 377-395. doi:10.1080/09538259.2018.1498583.

Morgan, J. 2019. 'Will We Work in Twenty-First Century Capitalism? A Critique of the Fourth Industrial Revolution Literature'. Economy and Society 48 (3): 371-398. doi:10.1080/03085147.2019.1620027.

Muller, J. 2017. 'Universities and the "New Society"'. In J. Muller, N. Cloete and F. van Schalkwyk (eds), Castells in Africa. Cape Town: African Minds, 17-34.

Mustafin, A. 2018. 'Kondratiev Long Cycles: New Information about Discussions in the USSR in the 1920s'. Working Papers Series: Humanities 168/Hum/2018. Moscow: National Research University Higher School of Economics. https://papers.ssrn.com/sol3/papers.cfm?abstract_id=3269221.

Nijman, J. and Y. D. Wei. 2020. 'Urban Inequalities in the 21st Century Economy'. Applied Geography 117: 1-8. doi:10.1016/j.apgeog.2020.102188.

OECD (Organisation for Economic Co-operation and Development). 2019a. OECD Employment Outlook 2019: The Future of Work. Paris: OECD Publishing.

OECD (Organisation for Economic Co-operation and Development). 2019b. Under Pressure: The Squeezed Middle Class. Paris: OECD Publishing.

OECD (Organisation for Economic Co-operation and Development). 2020a. OECD Employment Outlook 2020: Worker Security and the COVID-19 Crisis. Paris: OECD Publishing.

OECD (Organisation for Economic Co-operation and Development). 2020b. 'Trade Union and Collective Bargaining Statistics'. OECD.stat. https://stats. oecd.org/Index.aspx?DataSetCode=TUD (accessed 8 November 2020).

Omoju, J. O. 2017. 'IT Services Offshoring to Africa: Assessing the Attractiveness and the Readiness of Nigeria'. The African Journal of Information Systems 9 (2): 102-127. https://digitalcommons.kennesaw.edu/ ajis/vol9/iss $2 / 2$.

Papageorgiou, T. and P. G. Michaelides. 2016. 'Joseph Schumpeter and Thorstein Veblen on Technological Determinism, Individualism and Institutions'. The European Journal of the History of Economic Thought 23 (1): 1-30. doi:10.1080/09672567.2013.792378.

Perez, C. 2002. Technological Revolutions and Financial Capital: The Dynamics of Bubbles and Golden Ages. London: Edward Elgar.

Polanyi, K. 1945. Origins of Our Time: The Great Transformation. London: Victor Gollancz.

Pollard, S. and C. Holmes, (eds). 1972. Industrial Power and National Rivalry 1870-1914. London: Cox and Wyman.

Potter, E. E. 2003. 'Telecommuting: The Future of Work, Corporate Culture, and American Society'. Journal of Labor Research 24 (1): 73-84. doi:10.1007/s12122-003-1030-1. 
Rifkin, J. 1995. The End of Work: The Decline of the Global Labor Force and the Dawn of The Post-Market Era. New York: Putnam.

Rifkin, J. 2011. The Third Industrial Revolution: How Lateral Power Is Transforming Energy, The Economy, and the World. New York: Palgrave MacMillan.

Rosenberg, E. 2020. 'Workers Are Fired Up. But Union Participation Is Still on the Decline, New Statistics Show'. Washington Post, 23 January. https:// www.washingtonpost.com/business/2020/01/22/workers-are-fired-up-unionparticipation-is-still-decline-new-statistics-show/.

Schön, L. 2007. 'Technological Shifts and Convergence in a European Perspective since 1950'. Scandinavian Economic History Review 55 (3): 222-243. doi:10.1080/03585520701768701.

Schumpeter, J. A. (1943) 1976. Capitalism, Socialism and Democracy. London: Routledge.

Schwab, K. 2016. The Fourth Industrial Revolution. Geneva: World Economic Forum.

Scoville, J. 2001. 'The Taylorization of Vladimir Ilich Lenin'. Industrial Relations 40 (4): 620-626. doi:10.1111/0019-8676.00228.

Seabrooke, L. and D. Wigan. 2014. 'Global Wealth Chains in the International Political Economy'. Review of International Political Economy 21 (1): 257263. doi:10.1080/09692290.2013.872691.

Stearns, P. N. 2012. The Industrial Revolution in World History. Boulder, CO: Westview Press.

Steger, M. 2009. Globalization: A Very Short Introduction. New York: Sterling. Takanishi, A. 2019. 'Historical Perspecive of Humanoid Robot Research in Asia'. In A. Goswami and P. Vadakkepat (eds), Humanoid Robotics: A Reference. Dordrecht, The Netherlands: Springer, 36-52.

Taylor, F. W. (1911) 1967. The Principles of Scientific Management. New York: Norton.

Teicher, J. 2018. 'The Little-Known Story of the First IoT Device'. IBM Industries Blog, 7 February. https:/www.ibm.com/blogs/industries/littleknown-story-first-iot-device/.

Thompson, E. P. 1963. The Making of the English Working Class. London: Victor Gollancz.

Toniolo, G. 1998. 'Europe's Golden Age, 1950-1973: Speculations from a Long-Run Perspective'. The Economic History Review 51 (2): 252-267. doi:10.1111/1468-0289.00090.

Topping, A. 2017. 'Union Membership Has Plunged to an All-Time Low'. The Guardian, 1 June. https://www.theguardian.com/politics/2017/jun/01/unionmembership-has-plunged-to-an-all-time-low-says-ons.

Toynbee, A. 1884. Lectures on the Industrial Revolution in England. London: Rivington's. (Digitised by Harvard University, 2008). https://archive.org/ details/lecturesonindus01jowegoog/mode/2up. 
UN (United Nations). 2020. World Social Report 2020: Inequality in a Rapidly Changing World. New York: United Nations Department of Economic and Social Affairs.

Van de Velde, W. (ed.). 1993. 'Introduction'. In Toward Learning Robots. Cambridge, MA: MIT Press, 1-17.

Virdee, S. and B. McGeever. 2018. 'Racism, Crisis, Brexit'. Ethnic and Racial Studies 41 (10): 1802-1819. doi:10.1080/01419870.2017.1361544.

Visser, J. 2019a. 'Can Unions Revitalize Themselves?' International Journal of Labour Research 9 (1-2): 17-48. https://www.ilo.org/wcmsp5/groups/ public/---ed_dialogue/---actrav/documents/publication/wcms_731147.pdf.

Visser, J. 2019b. 'Trade Unions in the Balance'. ILO ACTRAV Working Paper. Geneva: International Labour Organization. https:/www.ilo.org/actrav/info/ pubs/WCMS_722482/lang--en/index.htm.

Wahl-Jorgensen, K. 2018. 'Media Coverage of Shifting Emotional Regimes: Donald Trump's Angry Populism'. Media, Culture and Society 40 (5): 766778. doi:10.1177/0163443718772190.

Wallerstein, I. 1984. 'Long Waves as Capitalist Process'. Review (Fernand Braudel Center) 7 (4): 559-575. https://www.jstor.org/stable/40240968.

Warda, P. 2013. 'Trends and Patterns in Offshoring in the European Automotive Industry'. In C. Karlsson, B. Johansson and R. Stough (eds), Entrepreneurial Knowledge, Technology and the Transformation of Regions. London: Routledge, 118-143.

Webster, E. and K. Forrest. 2019. 'Precarious Work: Experimenting with new Forms of Representation: South African Labour Responds'. International Journal of Labour Research 9 (1-2): 49-72. https://labordoc.ilo.org/ discovery/fulldisplay/alma995087393202676/41ILO_INST:41ILO_V2.

Wikipedia. n.d. 'History of Robots'. Wikipedia. https://en.wikipedia.org/wiki/ History_of_robots (accessed 19 June 2020).

Williams, E. (1944) 1994. Capitalism and Slavery. Chapel Hill, NC: University of North Carolina Press.

Wits University (University of the Witwatersrand). 2019. 'Wits Researchers Interpret Brainwaves to Give Amputees a Hand'. Daily Maverick, 26 November. https://www.dailymaverick.co.za/article/2019-11-26-witsresearchers-interpret-brainwaves-to-give-amputees-a-hand/.

World Bank. 2020. 'GDP per Capita'. https://data.worldbank.org/indicator/ (accessed 8 November 2020).

Yerkey, G. 1984. 'Robot Boom Hits "Plateau" in West as Technology Costs Set Limits'. The Christian Science Monitor, 16 November. https://www. csmonitor.com/1984/1116/111624.html.

Zittrain, J. 2008. The Future of the Internet - And How to Stop It. New Haven, CT: Yale University Press. 